\title{
Certain International and Criminal Law Aspects of the Use and Circulation of Weapons and Ammunition During Interstate or Civil Armed Conflicts
}

\author{
Kofanov Andrii \\ Legal Advisor to the Council of Europe Programme "Decentralization and \\ Territorial Consolidation in Ukraine”, PhD of Juridical Sciences, Associate \\ Professor, Professor of Department of Forensic Support and Forensic Expertise \\ of the National Academy of Internal Affairs, Kiev, Ukraine \\ ORCID ID 0000-0002-5242-2518_kofanov_andrey@ukr.net
}

\section{Kulyk Maryna}

PhD of Juridical Sciences, Associate Professor of Forensic Support and Forensic Expertise of the National Academy of Internal Affairs, Kiev, Ukraine ORCID ID 0000-0003-1373-6749 coolss777@ukr.net

\section{Morhun Nadiia}

PhD of Juridical Sciences, Deputy Director of Educational and Research Institute №1 for educational, scientific and research works, National Academy of Internal Affairs, Kyiv, Ukraine ORCID ID 0000-0002-2997-9975 protektra@i.ua

\section{Kutsyi Roman}

PhD of Juridical Sciences, Senior Teacher of Criminal Law Disciplines and Operative and Investigative Activities of the Precarpathian Department of the

National Academy of Internal Affairs, Kyiv, Ukraine ORCID ID 0000-0002-1979-7019 romakrv2009@ukr.net

\section{Stepanova Hanna}

PhD of Juridical Sciences, Associate Professor of Forensic Support and Forensic Expertise of the National Academy of Internal Affairs, Kiev, Ukraine ORCID ID 0000-0003-1280-0163 annast7675@ukr.net

\footnotetext{
Abstract

At its 63rd session, the UN General Assembly noted that present-day armed conflicts blurred the distinction between international and internal armed conflicts. The number of civil wars has increased, and, statistically, they are more frequent than international armed conflicts. Furthermore, many of these 'civil wars' include 'external' components, such as support and involvement, in varying degrees, by other states that supply arms, provide training camps, financial resources, etc. The existing international humanitarian law contains provisions that govern the use of weapons. They may be divided into groups: 1. Banning and restricting specific
} 
types of weapons under international treaties. 2. Banning and restricting certain types of weapons, such as poison, biological and chemical weapons, under traditional international law. 3. General principles that govern the use of weapons under international humanitarian law.

The first principle involves distinction between military objectives and civilian population, between combatants and civilians during the war. It originated in the St. Petersburg Declaration Renouncing the Use, in Time of War, of certain Explosive Projectiles dated 1868 and was subsequently codified in the Additional Protocol I of 1977 (Article 48). The second important principle involves proportionality. The scale of destruction in the conduct of a military operation should be commensurate with the importance of this operation. Article 57, Additional Protocol I of 1977, stipulates that those who plan or decide upon an attack shall take all feasible precautions in the choice of means and methods of attack, and refrain from deciding to launch any attack which may be expected to cause incidental loss of civilian life. Obviously, any kind of restriction is a question of ethics and morality and therefore may be discussed and interpreted differently. As regards restrictions on certain types of weapons, it is essential to have methods that would enable taking reliable and efficient measurements of the environment and consequences of a projectile impact as a means of attacking personnel, materiel and fortifications. Having common criteria for the results obtained through the use of these methods is equally important. All international treaties concerning the use and application of firearms have continuously reiterated two aspects: 1) a party's entitlement to an unlimited choice of weaponry to inflict damage to the enemy; 2) restricting the use of weapons that cause 'unnecessary suffering'.

International legal regulation of warfare is intended to restrain parties to an armed conflict from wanton cruelty. Violations of these rules, either with criminal intent or because of criminal negligence, are recognised as war crimes.

The international community is also increasingly recognising the threat of arms trafficking not only as the countries' internal problem, but also as a significant factor of influence on transnational organised crime, including drug trafficking, money laundering, financing of terrorism, etc. The illicit trafficking in firearms, explosive substances and devices has always posed a serious threat to public safety. The key suppliers and intermediates in the global arms trafficking primarily represent transnational organised crime. It is these organisations that mostly operate in the areas of armed conflict and in adjacent countries. Illicit trade in small arms is the most widespread globally, given their easy use, availability, and opportunities for rapid replenishment of ammunition. These weapons are legal per se; selling them to banned purchasers is illegal. These purchasers usually include those countries whose governments allow conflicts or violations of human rights both within and outside the country. The proliferation of weapons has assumed organised forms long ago, and the main reason for its prevalence is its exceptional profitability. Therefore, signing of the Protocol against the Illicit Manufacturing and Trafficking in Firearms, Their Parts and Components and Ammunition on 02/03/2001, as a supplement to the UN Convention against Transnational Organised Crime, became an important step in the development of international legal rules in the field of combating the illegal trafficking in firearms. Recently, the movement of weapons across Ukrainian borders beyond or concealed from customs control has become of particular concern, as evidenced not only by a higher public danger of such acts, but also by the associated negative processes that tend to be further exacerbated [1].

Key words: The Law 'On Weapons', firearms circulation, firearm registration and monitoring.

Introduction After 1850, in order to increase impact on hard targets, many countries produced ammunition that was guaranteed to disable enemy personnel. Thus, explosive and incendiary shells appeared, comprising a hollow body with gunpowder or incendiary agent and a fuse. At first, no restrictions existed on the use of such shells during hostilities. However, military surgeons treating the personnel with gunshot wounds noticed a hugely disproportionate amount of damage caused by explosive bullets. Rather than being restricted to disabling the enemy, the action of the bullet caused major damage, resulting in lethality or severe disability among soldiers. It was no surprise that, almost immediately after these projectiles were put into service, the public, mostly doctors, started calling for a ban on them. 
The initiative to restrict the use of 'non-humane' bullets belonged to the Russian Empire which organised a conference held in St. Petersburg in December 1868. The outcome of the conference was the Declaration adopted on 11/12/1868. It established the principles of 'restriction'. It stipulated inter alia that the objective of a warring country may not include the use of weapons that cause 'unnecessary suffering'.

The Contracting Parties renounced the employment of any projectile of a weight below 400 grams, which was either explosive or charged with fulminating or inflammable substances. This mainly concerned explosive bullets.

In the opinion of the International Committee of the Red Cross, the Declaration of St. Petersburg of 1868, which bans the use of explosive bullets, is the cornerstone of efforts to protect soldiers from excessive damage and unnecessary suffering.

In 1874, merely six years later, in 1874, a second conference was held in Brussels to limit the destructive power of projectiles. Again, the Russian Empire was the initiator. The Conference adopted a draft Project signed in August 1874. By laying the foundation for subsequent treaties, the draft Project was of critical importance, since the Brussels Conference managed to agree the key provisions. For example, Article 12 stated that 'the laws of war do not recognise in belligerents an unlimited power in the adoption of means of injuring the enemy,' whereas Article 13 forbade 'the employment of arms, projectiles or material calculated to cause unnecessary suffering.' The draft Project also reaffirmed the ban imposed on explosive bullets by the Declaration of St. Petersburg. Furthermore, the draft Brussels Project restricted the employment of poison or poisoned weapons.

In 1899, the Russian Empire initiated another conference on limitation of armaments, where it proposed that technological development of guns and hand-held weapons be frozen for at least 5 years. Attention was drawn to different wordings of the quality of hand-held weapons, based on their specific types, weight, projectile calibre, initial velocity and rate of fire. Unfortunately, none of the proposals was ratified by most European countries. The discussion on limiting the impact of weapons continued. Nevertheless, a new Convention was adopted in The Hague in 1899, reaffirming Article 12 of the draft Brussels Project.

By the end of the 19th century, a dumdum bullet had become widespread in a number of countries. Despite its obvious heavy destructive power, disagreements arose around the criteria for its banning. Proponents of this bullet argued that the dumdum bullet was not explosive in the 
meaning of the St. Petersburg Declaration. After a lengthy discussion, it was written in the final version of the Hague Convention that 'The Contracting Parties agree to abstain from the use of bullets which expand or flatten easily in the human body, such as bullets with a hard envelope which does not entirely cover the core.' Thus, the Hague Convention of 1899 prohibited the development and use of deforming and, in particular, semi-jacketed bullets.

On 18/10/1907, The Hague once again hosted an international conference dedicated to a wide range of issues associated with observance of the rules, laws and customs of war. The event was attended by representatives from 44 countries. The new Convention, entitled the 'Convention with respect to the Laws and Customs of War on Land', explicitly stated that 'the right of belligerents to adopt means of injuring the enemy is not unlimited.' It was expressly forbidden 'to employ arms, projectiles, or material of a nature to cause superfluous injury.' Once again, opponents of limitations on the stopping power of weapons tried to protect dumdum-type bullets by alleging that the direct bans imposed by the St. Petersburg, Brussels and Hague Conferences had not been formally reaffirmed in the 1907 Convention [2].

Discussions around the problem of limitations on the stopping power of weapons were continued in 1980, when a special conference was held in Geneva under the UN auspices. This had to do with the fact that, in the 1960s, small-calibre 5.56mm cartridges for the U.S. M16A1 assault rifle became widespread [3]. This projectile met all the requirements imposed on a jacketed bullet; however, its behaviour in soft biological tissues resembled that of a dumdum bullet. It was precisely this circumstance that prompted the public to revisit the problem of limiting the stopping power of ammunition. Initially, the matter of reducing the initial muzzle velocity to $800 \mathrm{~m} / \mathrm{s}$ was considered, since the standard speed of $990 \mathrm{~m} / \mathrm{s}$ and the low stability of the bullet along the external ballistic trajectory resulted in serious consequences when in contact with a biological target [3]. This was also exacerbated by the design features of the bullet that had a hollow in its head. The most vocal demands were to ban the $5.56 \mathrm{~mm}$ bullets completely [3]. This bullet was banned neither then nor later.

In view of this, extensive tests were performed in the 1970s by ballistics experts in various countries to study the behaviour of small-calibre projectiles in soft biological tissues. Not all the researchers had achieved consistent results. This was largely due to the fact that the logistical and methodological base differed significantly between the countries. This had a major influence on decisions of the 1980 UN Geneva Conference, where detailed reports of scientists from various 
countries were heard. Nevertheless, the Conference adopted a number of rules that represented requirements both on ammunition and on experimental work's scientific accuracy, which is capable of ensuring comparability of findings. The key outcomes of the Geneva Conference were as follows: 1) bullets fired from hand-held small arms should have limits on the energy transferred to soft biological tissues; 2) prohibit the use of explosive projectiles; 3) prohibit to use any weapon the primary effect of which is to injure by fragments which in the human body escape detection by X-rays; 4) unify the techniques for assessing the stopping power of projectiles by using $14 \mathrm{~cm}$-thick blocks of transparent ('ballistic') soap as a simulant at a range of $100 \mathrm{~m}$.

In the 1990s, democratic forces attempted to ban the use of AK-74 5.45mm bullets and to remove them from the Russian army's inventory [3]. This demand was largely political in nature. However, it necessitated a thorough comparison study of stopping power between Russian and other foreign small-calibre ammunition for hand-held firearms. Findings of the comparison study made it possible to draw the following conclusion: 1) the emergence of small-calibre (5.45 and $5.56 \mathrm{~mm}$ ) ammunition for hand-held firearms is a natural and logical step in perfecting weapons and ammunition and is a common process observed in various countries of the world [3]; 2) unlike the $5.56 \mathrm{~mm}$ M16A1 bullet that, when hitting the muscles, fragments into numerous splinters, the $5.45 \mathrm{~mm}$ bullet for AK-74, despite having a high stopping power, does not break in soft tissues [3]. Moreover, it was explained to the 'proponents of the bullet ban' that the relevant information had been communicated to the UN Geneva Conference and the International Red Cross back in the 1980s without any critical comments from these organisations.

Other means of attacking the enemy personnel, materiel and fortifications have not been overlooked. For example, the Convention on Prohibitions or Restrictions on the Use of Certain Conventional Weapons Which May Be Deemed to Be Excessively Injurious or to Have Indiscriminate Effects (Geneva, 10/10/1980), and Protocol II (as amended) thereto, which came into force in December 1998, are sometimes also called the Convention on Certain Conventional Weapons, or the Inhumane Weapons Convention (the 'IWC') [2].

The ICW is an international legal instrument governing the use of such types of weapons as land mines, booby-traps, and similar devices in conflicts.

Smuggling was attributed to crimes whose specific feature is the requirement for availability of an item directly targeted by a person's criminal activities, and through which (s)he impinges on the social relations that describe the target of this crime. Thus, an item of smuggling 
as a basis for the emergence and a condition for realisation of social relations, the content of which comprises its entities' economic activity, substantiates and highlights precisely this social category. This kind of economic relations was codified and substantiated in the items whose exhaustive list was contained in Article 201.1 of the Criminal Code of Ukraine (the 'CrCU').

When considering the concept of weapons, which, under Article 201.1 of the CrCU, are included in the items of smuggling, the following circumstances should be noted:

1. The domestic law provides no exhaustive definition of the concept of 'weapons'. This is evidenced, in particular, by the existence of seventeen draft Laws of Ukraine 'On Weapons' submitted to the Verkhovna Rada of Ukraine between 01/01/1995 and 01/09/2019. In all these draft Laws, weapons are defined as devices, accessories and items that are specifically manufactured, designed and technically suitable for stopping a human or other target, or protecting against attack. One of the best of them, the eighth (in order of publication) draft Law No. 1171 dated 22 November 2002 defines weapons as devices, accessories and items that are specifically manufactured, designed and technically suitable for stopping a human or other target and that serve no other industrial or household purpose.

Similarly, not a single regulation provides and exhaustive definition of 'weapons'.

2. When commenting on the concept of 'weapons' as an item of smuggling, certain scholars restrict themselves only to pointing out that, under Article 201 of the $\mathrm{CrCU}$, both firearms (other than for smooth-bore weapons) and cold weapons were understood as weapons. This was usually followed by references to a comment to Articles 262 and 263 of the CrCU. The legislator refers to firearms (other than smooth-bore shotguns), ammunition, explosives, explosive devices and radioactive materials in Article 262 of the $\mathrm{CrCU}$, as well as to cold weapons in Article 263 of the $\mathrm{CrCU}$, as targets of a crime. This definition of weapons automatically restricts them to two types - firearms and cold weapons. O. O. Dudorov regards the following weapons as items of smuggling: 1) firearms (small arms, artillery, and shoulder-fired rocket launchers), rocket, missile, mine, incendiary, torpedo and other common types of military weapons; 2) nuclear, chemical, biological, laser, infra-sound, radiological and other weapons of mass destruction; 3) cold weapons; 4) nerve gas weapons; airguns with a calibre over $4.5 \mathrm{~mm}$ and bullet velocity exceeding 100m per second [3]; special weapons for firing rubber bullets; stun guns. The technical (forensic) group comprises several parts that determine its functionality (barrel, firing mechanism, etc.) and production (weapons must be specifically manufactured according to their 
intended purpose, such as active self-defence). Unlike the legal group, the technical one is not completely exhaustive. It is constantly changing, in line with the development of certain branches of science and technology, emergence of new technologies in the weapons manufacture. Therefore, in order to give a precise definition of the concept of 'weapons', all their technical features without exception should be taken into consideration, which is a logical impossibility. The only drawback to the above doctrinal definitions is that the authors failed to give a complete classification of weapon types, by leaving out, for example, combined weapons (that integrate rifled and smooth bores, or have a smooth bore grooved at the muzzle, or combine firearms and cold weapons) and explosive weapons (devices and accessories designed to stop a human or other target by an explosive charge effect), etc.

3. Under Article 201.1 of the CrCU, smooth-bore shotguns are not included into smuggled firearms. A smooth-bore weapon is a type of firearm intended for firing from smooth barrels without rifling. It is therefore not entirely clear what O. O. Dudorov meant by defining it as a weapon 'whose design does not allow firing a rifled bullet.'

Smooth-bore weapons constitute those that are industrially produced for the needs of hunting sector. Their sole purpose is hunting and they are in no way suited for combat operations. Therefore, making a sawn-off shotgun from a smooth-bore hunting weapon (by sawing off a part of the barrel and/or butt) increases the public danger of this item. In other words, by changing its original purpose, a particular shotgun changes its classification from a standard smooth-bore hunting weapon to a custom-made converted firearm.

4. Given the above, it should be noted that the concept of 'weapons' under Article 201.1 of the $\mathrm{CrCU}$ should be replaced to include specific types (firearms, explosive, special military weapons; cold, gas, air, and combined weapons), the definition of which must be provided in a dedicated Law of Ukraine 'On Weapons' [4].

Conclusion Public danger of rifled firearms is manifested in penetrability and accuracy of fire. As such, rifled barrels increase the range and penetrative power of bullets. It is assumed that the idea behind these definitions (i.e. defining a weapon through its classification) is commendable, since the concept of 'weapon' is a comprehensive category in the sense of criminal law. Its comprehensiveness is manifested by having two groups legal and technical (forensic) — of interrelated features. The legal group includes the following: first, objective elements that describe the external aspect and the modus operandi 
(use of weapons); second, subjective elements, i.e. deliberate and wilful attitude towards the action on the part of a person using the weapon; third, an element of legitimacy in using the weapon.

\section{References}

1. Theoretical and Practical Aspects of Arms Trafficking. URL: http://www.intellectualarchive.com/Journal_Files/IAJ_2019_02_011.pdf https://doi.org/10.32370/IA_2019_02_11

2. Popov V.L., Shigeev V.B., Kuznetsov L.E. Forensic ballistics. - St. Petersburg: Hippocrates, 2002. $-656 \mathrm{p}$.

3. Forensic examination of firearms, ammunition and shot traces (forensic ballistics). URL: http://elar.naiau.kiev.ua/jspui/handle/123456789/10710

4. Berzyn P.S. Some problems of defining weapons as a subject of smuggling / Ballistic forensic research and related areas of knowledge / First International Scientific and Practical Seminar. - K. : NNIPSK KNUVS, 2009. - 156 p. 